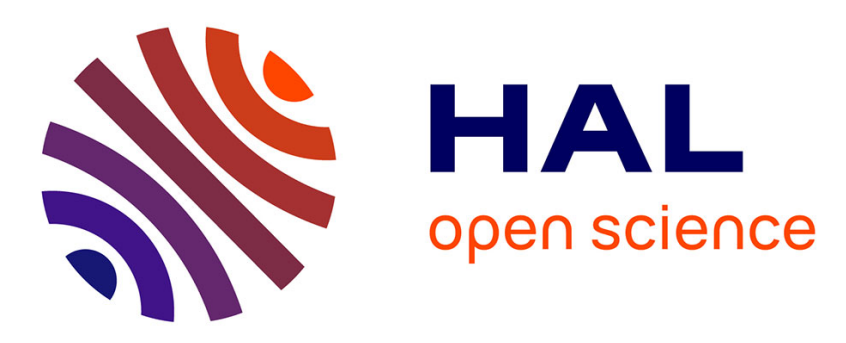

\title{
Green belts in the hands and minds of farmers: a socio-agronomic approach to farmers' practices
}

\author{
F. Alavoine-Mornas, Sabine Girard
}

\section{To cite this version:}

F. Alavoine-Mornas, Sabine Girard. Green belts in the hands and minds of farmers: a socio-agronomic approach to farmers' practices. Journal of Rural Studies, 2017, 56, pp.30-38. 10.1016/j.jrurstud.2017.09.005 . hal-01899071

\section{HAL Id: hal-01899071 https://hal.science/hal-01899071}

Submitted on 19 Oct 2018

HAL is a multi-disciplinary open access archive for the deposit and dissemination of scientific research documents, whether they are published or not. The documents may come from teaching and research institutions in France or abroad, or from public or private research centers.
L'archive ouverte pluridisciplinaire HAL, est destinée au dépôt et à la diffusion de documents scientifiques de niveau recherche, publiés ou non, émanant des établissements d'enseignement et de recherche français ou étrangers, des laboratoires publics ou privés. 
Alavoine-Mornas, F. ; Girard, S.

\section{Green Belts in the Hands and Minds of Farmers: a Socio-Agronomic Approach to Farmers' Practices}

\section{Background and issues}

There has been a dramatic decline in biodiversity over the last decades which can in part be attributed to the fragmented habitats of animal and plant species. Various public policies have been implemented to address this current threat. In France, a "green-and-blue belt" regulatory provision was set up by the law known as the Grenelle II Act of 12 July 2010. The aim of this provision is to maintain or restore land and freshwater ecological continuities, and to form a coherent ecological network for species' movement. These notions are underpinned by concepts developed in landscape ecology, which has established that the fragmentation of habitats, the narrowing of their diversity, and the reduction of their surface areas, affect the movement of species and jeopardise their survival (Jongman, 1995; Collinge, 1996; Burel and Baudry, 1999). In their meta-analysis of experiments addressing the issue of ecological corridor efficacy, GilbertNorton et al. (2010) show that such corridors tend to increase the movement of animal and plant species between different habitat patches.

Among the various public policies aiming to preserve biodiversity and the natural environment, those targeting green and blue belts particularly affect agriculture for several reasons. Seminatural features are often located in farm areas and are managed by farmers. In the context of implementing green belt provisions, farmers are faced with the challenge of ensuring a profitable production while at the same time following the rules set up to protect biodiversity. Moreover, while the landscape transformations leading to fragmented habitats are caused by multiple factors such as urban sprawl, expanding transport infrastructures, increasing traffic, land consolidation and draining of wetlands, modern intensive farming is often pointed to as a major driver of the collapse of wildlife populations and a threat to biodiversity conservation (Jongman, 2002; Henle et al., 2008), when in fact there are possible synergies between agriculture and biodiversity (Altieri, 1999; Grashof-Bokdam and Van Langervelde, 2004; Le Roux et al., 2008; Fleury et al., 2015; Magda et al., 2015).

The article deals with how agriculture contributes to the production and the maintenance of seminatural features that could form an ecological corridor. It will focus on the following questions: do farmers integrate the semi-natural features into their farming systems? What values do they place on those features? What reasons do they give to explain and justify their practices regarding semi-natural features? These issues were addressed within a research project: "Ecological networks in the Rhône-Alpes region, translations into planning projects and testing in agriculture" (PASSAGES) conducted as part of the DIVA III research programme (public action, agriculture and biodiversity) funded by the French Ministry of Ecology, Sustainable Development and Energy. One of the aims of this project was to analyse the links between the elements of green belt and farming activities and to identify and analyse farmers' practices and attitudes with respect to semi-natural feature and finally to provide information and decision support for public authorities.

Implementing public policy designed to preserve biodiversity in and by means of agricultural areas is often hindered by three main problems. Firstly, local stakeholders, scientists, naturalists and farmers have different views and perceptions of biodiversity, nature and the quality of nature 
(Hansen et al., 2006). Secondly, the notion of biodiversity is not spontaneously quoted by farmers (Larrère et al., 2007), and what makes sense for farmers is often nature and natural objects. Thirdly, policy makers are not sufficiently familiar with the diversity of farming practices (Girard, 2006), or the different considerations underpinning a farmer's frame of reference.

A number of studies have examined farmers' perception of biodiversity and the reasons why they engage in environmental schemes and adopt measures to preserve biodiversity. Many of these studies conclude that farmers who sign up to a biodiversity management contract or an agroenvironmental measure are spurred by reasons other than a purely financial reward. Thévenet et al. (2006) highlight factors such as farmers' attachment to places and traditional practices, the satisfaction they draw from their work being recognised or the feeling that they are protecting a common good. Van Dam et al. (2006) emphasise the role of emotions and sensations in farmers' relations with their natural environment. Siebert et al. (2006) consider that understanding farmers as "culturally situated" and tracing the values they attach to their farming behaviour may help explain why attempts to recruit farmers to biodiversity policies are not rejected on the grounds of rational decision-making alone. Farmers sometimes resist such policies because they represent a potential erosion of the identity they associate with being "good" farmers focused on productivity. These authors also note that while some farmers seem to pay attention to nature conservation, they may perceive nature-conservation policies as restrictions, bans and limitations. Barbier and Goulet (2012) underline the insights that can be drawn from analysing farmers' relations with natural objects and, more broadly speaking, with the "shape-objects" found on agricultural land (Deffontaines, 2004). Other researchers emphasise how farmers experiment with biodiversity as part of their daily practices (Kelemen et al., 2013), resulting in their perceptions of biodiversity being strongly embedded in their everyday lives and linked to farming practices.

These results suggest that farmers' practices are influenced by sociological factors among which farmers' social representations of the environment and their farming practices. Thus for MichelGuillou (2006), farmers share a common vision of the 'natural environment' that covers their respect for nature (a normative vision) and the love they have for their land (a functional vision). However, she also highlights individual differences in farmers' pro-environmental commitment and their opinion of the environment. The author argues that these differences may be linked to sociological factors such as social image, history and social or collective memory. Therefore farmers have to be seen as a heterogeneous group with a diversity of practices and values regarding biodiversity. Some authors carried out researches to describe and explain this diversity in attitudes and practices. Schmitzberger et al. (2005) use the concept of 'farming styles'. This term covers human attitudes, farming objectives and economic success, all of which are factors that can be used to assess the different ecological performance levels of farmers. Busck (2002) also refers to 'styles' which characterisation is based on the impacts of farmers' practices on landscape structures, the preparation farmers need prior to implementing landscape changes and the priority they give to overriding goals such as a profitable agricultural production, a pleasant place to live and wildlife protection.

Finally the literature explored offers little information about farmers' practices regarding a range of semi-natural features on farmland and the extent to which these are integrated into the farming system. Information about the rationale underpinning farmers' management and upkeep of each feature is likewise scarce. Moreover while some researchers have addressed the question of farmers' values and attitudes relating to biodiversity from a sociological or psychological point of view, they have not taken into account concrete farming conditions such as labour organisation, farmland spatial patterns, types of production or the overall running of the farm. 
The research presented here aims to develop a socio-agronomic approach in order to fill these gaps in knowledge and gain a more in-depth grasp of farmers' practices and representations regarding those semi-natural landscape features that could form part of a green belt. In addition, an understanding of the concrete factors able to help or hinder the implementation of green veining at the farm level should also be of service to policy makers.

After presenting the working method underlying this research, diverse farming practices with respect to semi-natural features on farmland shall be described. A typology of farmers based on the level of integration of the natural environment in the running of the farm shall then be proposed. The results shall next be discussed with an emphasis on the main findings which improve the knowledge of the subject as compared with the existing literature and certain aspects that could genuinely contribute to the implementation of green belt provisions by public authorities.

\section{Method}

\subsection{Conceptual framework}

The aim of our work was to identify farmers' practices regarding semi-natural features and to understand how farmers build their choices with respect to those features (removing or maintaining, upkeep...).To achieve this objective we adopted the frame of reference proposed by Darré et al. (2004) who argue that farmers' ways of thinking and knowledges can explain and justify their technical practices. This frame of analysis is a systemic approach applied by those agronomists who want to understand why farmers adopt some cropping systems or agricultural practices, and how they make their strategic and technical choices. This method leads agronomists to understand how farmers make their decisions through their own discourse and their own frame of reference.

Here we adapted this method to identify farmers' practices and perceptions with respect to seminatural features and biodiversity and to find out the reasons they quote to justify their practices. This type of approach is based on in-depth interviews in a small sample of farmers which provide a qualitative description of farmers' practices, perceptions and attitudes. The interviews have no quantitative or representative value. This method can help finding out the farmers' frame of reference and what makes sense for them when they build their decisions.

\subsection{The semi-natural features}

There is no current consensus in the literature on the definition and identification of the potential features of a green belt. Here, the focus is on landscape features able to provide channels for the movement of fauna and flora and hence act as biological corridors, favouring functional links between the ecosystems or habitats of diverse species, thereby allowing their dispersion and migration (COMOP TVB, 2010) ${ }^{1}$. It is considered that these features (i) must display permanency (Plantureux et al., 2012), which rules out, for example, temporary grasslands and annual crops, and (ii) be managed in a relatively extensive manner. This is why the following features have been taken into account: permanent grasslands with a minimum untilling period of 5 years, fallow lands, grassed strips (or buffer strips), woods, hedges and isolated trees. According to several authors and public French recommendations in the context of green veining, isolated trees as

\footnotetext{
${ }^{1}$ The biodiversity reservoirs formed in particular by protected areas have thus been left out of this work.
} 
well as hedges play a role in seeds dissemination and can be considered as significant part of ecological corridors to help species movements and biodiversity conservation by serving as habitats, corridors, or stepping stones for plant and animal species, adding structural and floristic complexity to the agricultural landscape and enhancing landscape connectivity (Harvey et al., 2004; Riley 2006; Dupraz, Liagre, 2011). Spatially, the semi-natural features form surfaces, lines or points. They are either productive, in the sense that they serve as a support for a farm production activity, or non-productive, i.e. have no direct role in such an activity.

\subsection{The area studied}

The work presented in this article is based on a survey conducted on a sample of farmers in the Isère river valley, referred to as the Gresivaudan valley, upstream of the city of Grenoble in the French Alps. This area is located between two mountain ranges, the Chartreuse and the Belledonne, and plays an important role for the movement of fauna between the massifs. A distinction can be made between the plain and the hillsides:

- The plain of the Isère river accommodates residential urbanisation, business parks, commercial areas, roads, motorways, railways and the Isère river itself, all of which are potential obstacles to the movement of fauna. Indeed, the farmers are faced with challenging periurban issues. Agricultural land is occupied by arable crops (in particular maize), walnut and fruit orchards, market gardening, and grasslands.

- The hillsides mark the transition between the plain and the mountains and offer abundant grasslands for stock farming (cattle and sheep) based on grassland systems ${ }^{2}$. This area is subject to a certain amount of urban pressure but it is also affected by the abandonment of agricultural land, which has notably led to the emergence of scrubland and forest encroachment.

The area specifically retained for the study covers nine municipalities in the Grésivaudan area, located some $40 \mathrm{~km}$ from Grenoble. It is of particular interest to the topic studied given the many semi-natural landscape features, diversified agriculture, periurban influences, and environmental issues.

\subsection{The interviews with the farmers and their analysis}

In all 20 farmers were included in the survey. According to the recommendations given by Darré et al. (2004), the sample was built so as to reflect the diversity of farming in Grésivaudan, in terms of farming system, farming area, farm size, location, etc. Since a large part of agricultural area is occupied by grasslands, the sample of farmers interviewed contains an important part of livestock farmers. The main types of farming among the farms surveyed were: livestock in 10 cases (suckler cattle in 6 cases, suckler sheep in 3 cases, and suckler sheep and goats in 1 case), arable crops in 3 cases (cereals and tobacco), walnuts ( 3 cases), fruit ( 3 cases), and market gardening (1 case). Farm size varied greatly both in terms of utilised agricultural area (from 2 ha for the market garden to 200 ha for one livestock farm), and herd size in the case of livestock farming (30-100 cows, 60-1000 sheep).

The survey consisted of semi-directive interviews with the farmers intended to let the respondents express their own answers and opinions with their own words on the different subjects addressed. At the beginning of each interview, an aerial photograph of the farmland area was presented to

\footnotetext{
${ }^{2}$ Grassland systems are supported inter alia by alpine grasslands located in uplands where livestock are put out to pasture in summer.
} 
the farmer who was invited to locate the semi-natural features of the farmland. This mapping approach provided a concrete basis for the discussion.

Then several topics were addressed during the interview. Some questions covered the presentation of the farm and its history; spatial management of the farmland, land use, farmer's objectives of production, farm functioning, farming system, farmer's main strategies. A second group of questions intended to let the farmer express his knowledge of his farm's semi-natural features (for example: does he know the names of the plant species present in the hedgerows or the meadows?), describe his practices with respect to these features (conservation or destruction, upkeep and management, use, time spent for the upkeep practices and their frequency, etc.) and the reasons underlying them. If differentiated practices were identified for the same type of feature, the farmer was invited to explain the reasons for which these practices were decided: for example, why he decided to remove a hedge and conserve another one, or why he used to trim a hedge or a tree every year but does not maintain other ones. A third issue in the interview was the farmer's perception of the natural environment (wild fauna and flora), and lastly his knowledge of the regulatory provisions in favour of biodiversity and his perception of his own contribution to the preservation of biodiversity and landscape.

Each interview lasted on average ninety minutes. Farmers' remarks were recorded and transcribed for analysis.

The analysis of the farmers' discourse comprised:

- An approach per semi-natural feature, which revealed the diversity of the farmers' knowledge, practices and attitudes with regard to each feature,

- An approach per farmer, which revealed different behavioural profiles with respect to the semi-natural features and different degrees of integration of the natural environment in the farming activity.

By comparing and contrasting the integration of features into overall farm functioning and the extent to which farmers' practices relating to these features differed, it was possible to establish a typology of farmer profiles.

\section{Results}

When the maps of the farmlands were presented and examined during the interviews with the farmers, semi-natural features could be seen to be present on all the farms. Hence, all the farmers surveyed were concerned by at least one type of semi-natural feature. It was therefore relevant to ask the farmers about the practices they implemented in order to manage these features.

\subsection{Farmers' practices in relation to semi-natural features and the reasons underpinning their choices}

The farms surveyed had between two and six different semi-natural features (Fig. 1). Two-thirds of them had more than four different semi-natural features. Wooded features were present most of all. Out of all the farms surveyed, $95 \%$ had woods, $85 \%$ hedges and $75 \%$ single trees. Fallow land and grassed strips were found to be less present (Fig 2). 


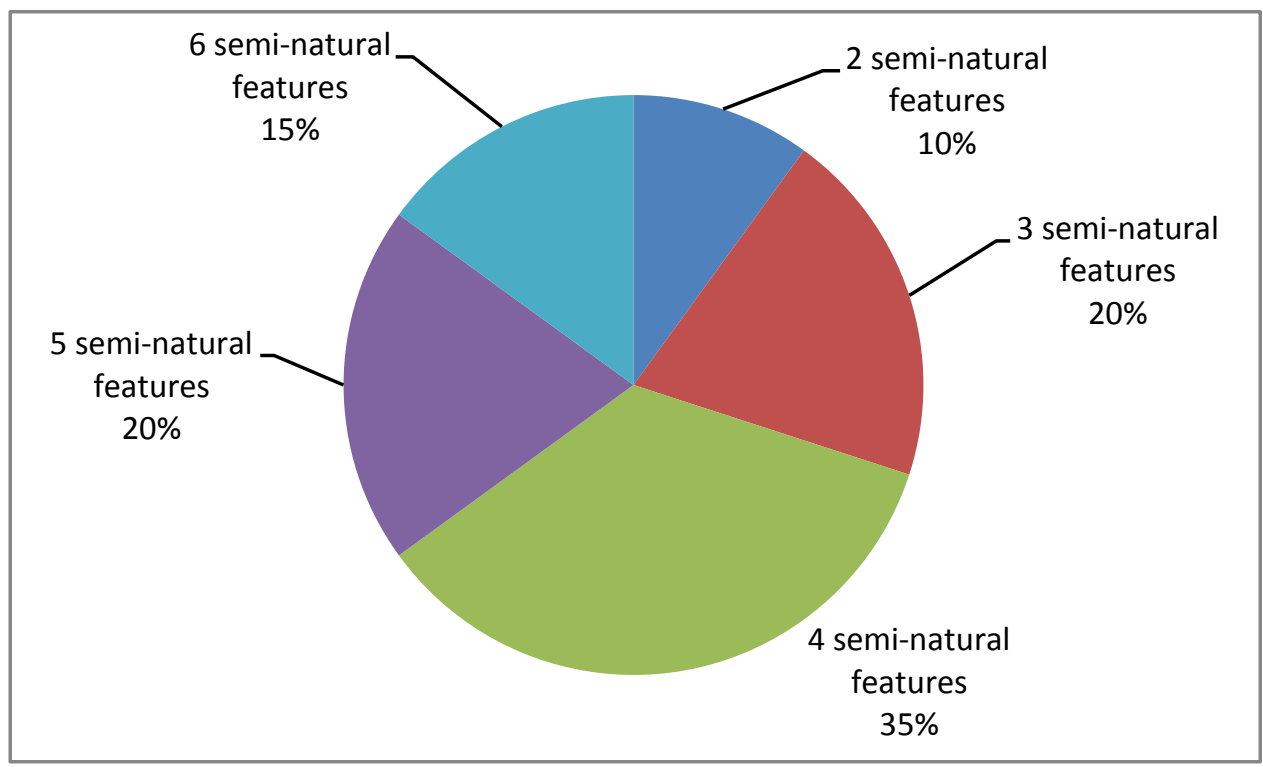

Figure 1: Percentage of farms surveyed according to the number of different semi-natural features

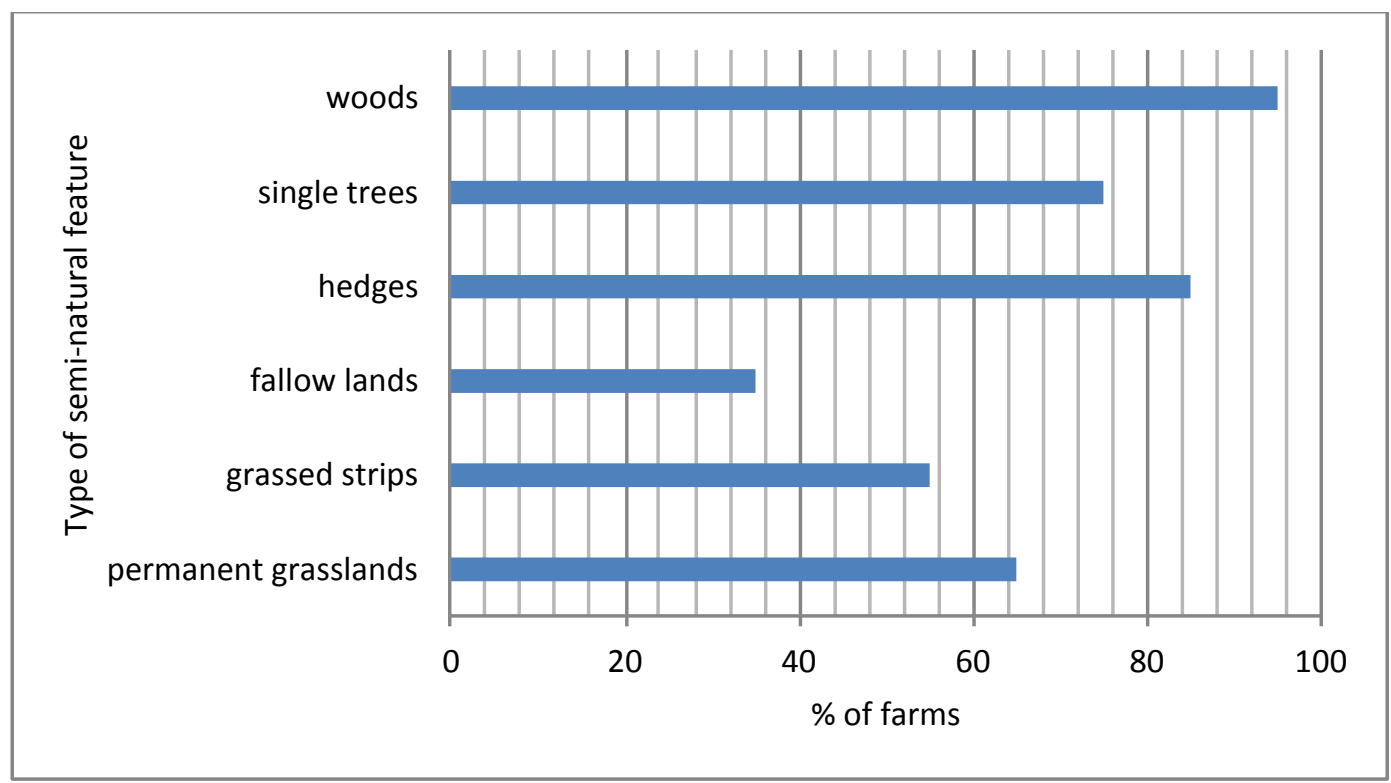

Figure 2: Percentage of farms surveyed concerned by each type of semi-natural feature

This next section addresses the choices made by farmers and the reasons behind them in terms of conservation, removal or implantation of semi-natural features, and practices ensuring the upkeep of these features and in particular their intensiveness. Firstly we present the results about grasslands which play a special role as productive features in some farms. Then we present the results for the other semi-natural features which are not directly linked to production activities.

\subsubsection{Grasslands}


Grasslands in some farms are directly linked to the production activity for livestock farming and forage production. So livestock farmers conserve grasslands as long as they are necessary to their production.

In such farms the production practices showed different levels of intensiveness which were fitted into the overall technical and economic functioning of the farm. The most intensive practices in the sample included regular soil amendment of grasslands (organic or chemical), several grazing periods or mowing operations per year (up to three), and wrapping in some cases. These practices were used on farms where livestock farming was the main activity and where forage was consumed on the farm. To justify these practices, farmers referred to objectives of optimised feed production and feed self-sufficiency. Production practices were less intensive when livestock farming or forage activity was a secondary activity. Plot configuration (shape, slope, accessibility, setting) and the distance of plots from the farmstead also conditioned the nature and intensiveness of production practices.

\subsubsection{Reasons to conserve or remove non-productive semi-natural features}

The first category of reasons given for conserving semi-natural features on a farm (other than permanent grasslands) stemmed from the farmer's perception of a utility, which was often not solely technical or economic utility. This notion of a feature's utility was balanced against the constraints arising from its presence. This was the case in particular for woods, hedges and isolated trees. On the contrary the absence of any perceived utility constituted a reason for removing a feature.

Some farmers associated a feature's utility with a production activity: livestock farmers emphasised that trees provided comfort for grazing animals, offering shade or a surface to rub against. In some cases, hedges and woods were seen to serve as natural boundaries ("keeping the animals from straying"), protecting the animals from dangerous areas (e.g. rocky ledges), helping to forestall land erosion, or harbouring beneficial organisms: "some insects, like Antochoris, hibernate in hedges, near fruit trees, near walnut trees. We don't pull them up because they can give shelter".

At times, a feature's utility was linked to a more personal use: production of firewood, picking or collection of fruit for family consumption (walnuts, cherries, apples, etc.). Some farmers also pointed to the heritage or landscape value of trees or hedges. Others claimed to be historically, culturally or sentimentally attached to trees, or referred to their aesthetic value: "these trees around the farm really let me breathe".

Lastly, some farmers considered that semi-natural features fostered the presence and movement of wildlife, offering a pleasure for the eye or game to hunt as a leisure activity. However, it should be noted that most of the farmers surveyed did not explicitly link the presence of this fauna to the conservation and management of semi-natural features, wildlife being most often seen in crop fields or alpine meadows.

Decisions to conserve or remove semi-natural features as well as upkeep practices thus varied greatly in time and space and according to the individual farmer. Choices were guided by the nature of the feature as well as by its density on the farm and its distribution over the agricultural area. The notion of a tolerance threshold was often implicit: the farmers seemed to conserve features so long as their utility outweighed their inconvenience. 
The absence of any hindrance ("it's not in the way"), or the longstanding presence of the feature ("the hedges are there, so we keep them, that's all"), formed the second category of reasons justifying the conservation of semi-natural features on the farm. In contrast some farmers removed features to avoid constraints or hindrances linked to production activities: damage caused to farm machinery by trees, or the time and effort required for upkeep: "the cabs get knocked about, mirrors get broken, so we have to raise the branches (...) the old folk had the time to trim back the thorns, but we haven't got the time any more", explained one livestock farmer. Other arguments included the reduction in available crop area (fallows), the competition of hedges, trees and woods with immediately adjoining crops, and nuisance effects (shade, damp, and the risk of disease appearing in crops). Some species were particularly unwelcome, such as acacia and other such "thorns", and firs.

The third category of reasons to conserve or remove a feature was tied to an obligation. This obligation might be regulatory in the case of grassed strips or fallow lands. When the regulatory provision is terminated the farmers can remove the grassed strips or fallow lands. However, some farmers, having been obliged to install or conserve these features, finally found them useful and decided to keep them even when the obligation no longer applied. For example, fallow land might be converted into permanent grassland.

The obligation to conserve a semi-natural feature can also be linked to land ownership when the owner wanted to conserve woods, hedges or isolated trees: "sure, without all these hedges we'd have one big field there! They could go... but it's not easy when you're not the owner". In other cases some farmers opted to conserve features delimiting a plot, in an effort to keep up good relations with the neighbours. Upkeep practices in such cases were most often minimal.

\subsubsection{Semi-natural features upkeep}

The survey showed that the intensiveness of semi-natural features upkeep was not linked to the intensiveness of production practices on the agricultural parcels. Intensive upkeep (frequent brush clearing and trimming, more than once a year, by mechanical or chemical means) was not necessarily associated with intensive production practices, and vice versa. Some farmers used technical and economic arguments to justify their relatively intensive practices for the upkeep of hedgerows and adjoining woodland, e.g. optimisation of neighbouring crop areas or forage quality, or preservation of fences. However, they also put forward other reasons tied to their perception of the farm landscape context or their view of their activity. For most of the livestock farmers surveyed, upkeep of grassland approaches contributed to the fight against encroachment and also reflected their concern about land abandonment and the future of livestock farming in the area. For others, this upkeep was above all a question of orderly farming, a show of work properly done: "cutting back edges makes tidy meadows". Therefore land use issues influence upkeep practices regarding semi-natural features: some farmers think that maintaining 'tidy' the grasslands and their approaches show to landowners the quality of their work. In their opinion this 'quality' of work could help them find new plots to rent if necessary.

To conclude, the farmers interviewed justified their choice to conserve or remove semi-natural features on the farm and their upkeep practices not solely on technical or economic grounds. They also put forward aesthetic, heritage-related or sentimental concerns when explaining their decision, as well as pointing to the importance of the well-being of their livestock. The diversity of farmers' practices and their justifications can be viewed at two levels. At the farm level, farmers 
might make different decisions concerning the same type of semi-natural feature according to its location, utility or inconvenience and the values associated with it. At the level of all the farmers surveyed, the different practices and justifications demonstrated that the farmers interviewed have different practices associated with different perceptions of semi-natural features. These findings make it possible to identify several farmer profiles.

\subsection{Four farmer profiles}

Four farmer profiles can be identified based on similar practices or reasoning regarding nonproductive semi-natural features (woods, hedges, isolated trees, fallow fields and grassed strips). The practices revealed in this study proved to be closely linked to how the farmers saw the natural environment in general, and the role they believed these features played in the functioning of the farm. The analysis of the farmers' discourse on the topics addressed in the interviews made it possible to identify two criteria which seemed relevant to characterise different profiles.

One aspect relates to the extent to which the natural environment was integrated into the farming activity. The results showed that on one side some farmers considered the natural environment (including semi-natural features) as harmful and a hindrance for the farming activity; in contrast other ones have integrated the natural environment into the farm functioning. Some cases showed an intermediary level between these two previous categories.

The second aspect reflects the degree of differentiation of the practices according to the feature. Some farmers tended to have non-differentiated practices with regard to semi-natural features while for others removal or maintaining of features as well as upkeep practices depended clearly on the characteristics of the feature considered.

Crossings these two axes (integration or non-integration of semi-natural features into the farm functioning vs differentiated or non-differentiated practices) led us to four farmer profiles which are schematically represented in Figure 3. 


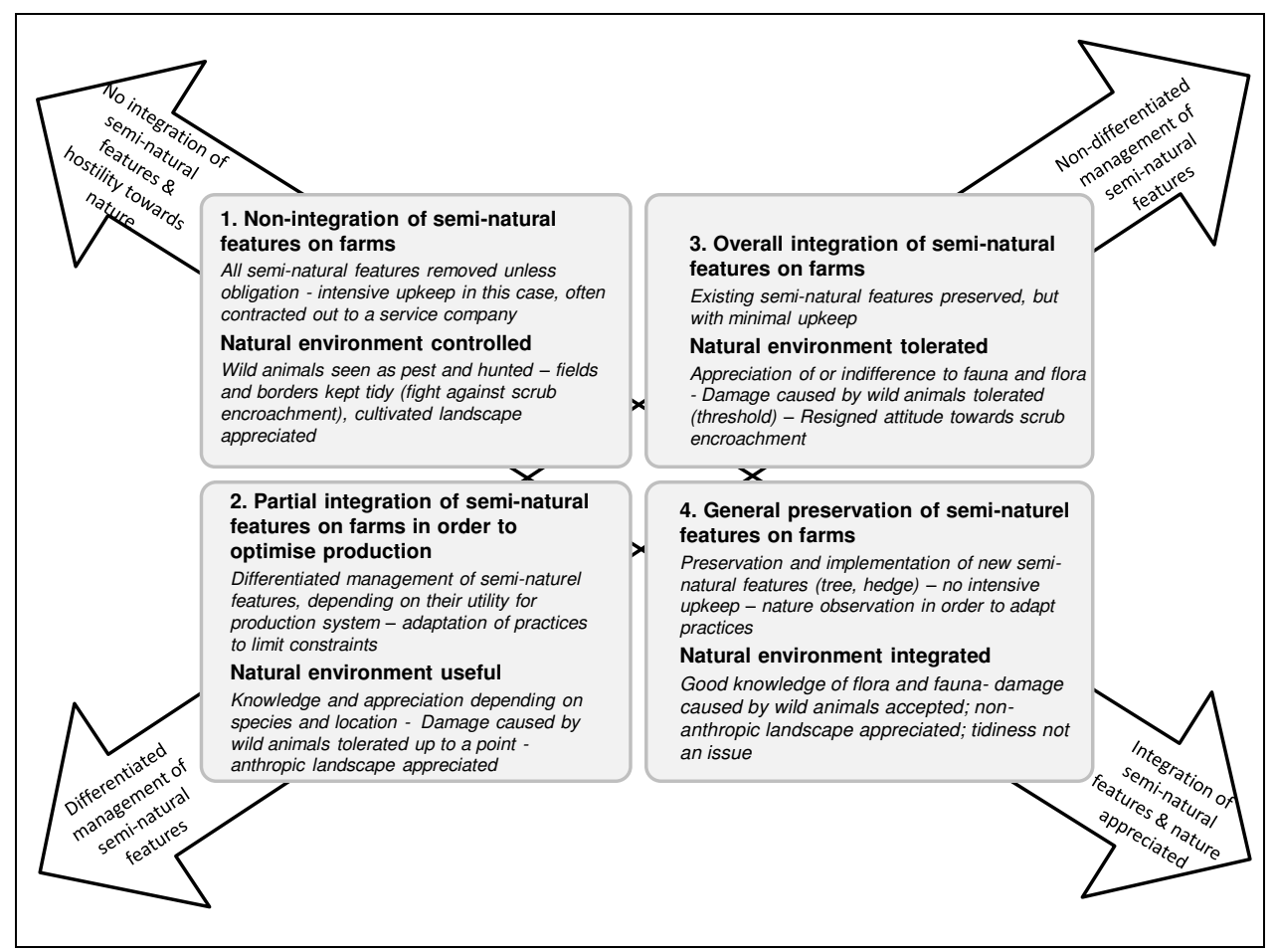

Figure 3: Four farmer profiles according to the management of non-productive semi-natural features on farms

\subsubsection{Group 1: Natural environment to be controlled, semi-natural features removed}

The first group of farmers ( 5 farmers) was characterised by the absence of any integration of the natural environment into their farming operation. These farmers viewed the natural environment as a threat to production activity. Their knowledge of wild fauna and flora was scant. Wild animals were perceived essentially as "pests" insofar as they could damage crops and farm equipment, or disturb livestock activities. Wild boar were particularly incriminated, and to a lesser extent deer, rabbits, rodents and crows: "damned wild boar can do a lot of damage to corn", complained one farmer. Such damage was not tolerated and the animals causing it were hunted down. Non-crop vegetation was essentially viewed as encroachment and described in negative terms ("thorns", "all these messy oak sprouts, rough weeds", "bushes, brambles, brushwood"). Landscapes found attractive were those that were farmed and well-kept, where a human presence was fully visible. Tidiness was emphasised and associated with work well done. For this group of farmers, the wild state, whether of animals or plants, had to be controlled and kept well apart from crops and livestock.

These farmers tended to remove any non-productive semi-natural features present on the farm, unless there was an obligation to conserve them. Grasslands, when they formed an important part of the production system, were managed intensively. No special attention was paid to mowing direction to let fauna escape: "I sometimes cut up game! Sometimes you cut its hind legs, [of deer], you stun it, if it's small we get rid of it, if it's a big one, we take it down at midday, skin it and eat it". Upkeep of grassland approaches was intensive, including treatment with chemicals. 
When financially possible, this upkeep was contracted out to a service company. Conversely, when grassland was not essential for production activity, and clearing it was too much trouble, then it might be left to overgrow.

\subsubsection{Group 2: Natural environment tolerated, semi-natural features generally conserved}

The second group of farmers ( 5 farmers) was characterised by partial integration of the natural environment in the running of the farm. The natural environment was present, with its attendant constraints, but with its possible advantages, and so the farmers accepted it. They had varying degrees of knowledge relating to wild fauna and flora, which they occasionally appreciated or to which they were indifferent. They tolerated damage done by wild animals, considering it to be either minor, or unavoidable: "there are more and more wild boar, I don't know what to do".

These farmers adopted practices for the general conservation of semi-natural features present on their farms because of some particular utility (trees and grasslands) or an obligation (set-aside, grassed strip), but most often because these features had always been there and were not a great hindrance: "the cows graze under the hedges, there's no problem (...) the trees, if they really get in the way, yes, we fell them, but if they're in a corner or on a mound..." Upkeep was minimal and general: "I go all round with the brushcutter". Although permanent grasslands were farmed with varying intensiveness, upkeep of their approaches was usually nominal. It depended generally on the time available, the cost and the work effort required.

\subsubsection{Group 3: Natural environment optimised, semi-natural features managed in different ways}

Like the second group, the third group of farmers (7 farmers) partially integrated the natural environment into the running of the farm, but this integration was differentiated according to various criteria. In some places, some wild animal or plant species were seen to be useful to the farming activity and so warranted conservation, e.g. beneficial organisms. On the other hand, other species were to be eliminated, the damage they caused being tolerable only up to a certain point. While some farmers put up with wild animals such as boar ("wild boar, we live with it, we have problems, we live with it"), others were less tolerant and organised themselves accordingly, most often with hunting federations: "wild boar are a big concern, we have kilometres of fences; we're pleased when the hunters kill a boar, it's good riddance". The natural environment was perceived essentially from a utilitarian standpoint. The farmers in this group had various degrees of knowledge and appreciation of the natural environment, according to their interest not only from the point of view of farm production, but also according to other criteria: "walnut trees look nice", "sometimes I've mown down a little deer, it's upset me for the rest of the day". They liked tidy landscapes ("I hate to see overgrown meadows"), which they farmed in various ways maintaining the presence of trees and hedges. These farmers congratulated themselves on the role they played maintaining this type of landscape: "it's the variety that makes it look nice", "if you've got just one crop in the valley, it's boring, and it's horrible because there's no life!"; "the countryside without farmers would just be woods (...) just thorns and brush, it wouldn't make you want to go for a walk in the country". They deplored the encroachment of woodland due to the abandonment of agriculture on hillsides: "we put the cows out to graze in the meadows, that way they're cleared, otherwise it wouldn't look nice."

The management of semi-natural features varied according to different criteria: they were removed when they were a hindrance, but conserved when seen to be useful, depending on the type of feature and its location on the farmland. For example, hedges were grubbed up where they got in the way of farm machinery, but kept near fruit trees because of the beneficial 
organisms they harboured. These farmers were also characterised by their optimisation and adaptation strategies. Set-asides and compulsory grassed strips were positioned on the plots located on the steepest slopes, and were the least accessible and the least productive. The management of permanent grasslands (production and upkeep of approaches) also varied greatly according to plot location and configuration and forage end use. The farmers in this group seemed to have a greater knowledge of their forage composition and paid particular attention to its nutritional quality and its appetence for their livestock: "[in my meadows], there's a bit of clover, cocksfoot, fescue, and where it's not so good, there's plantain and a few tufts of lucerne", explained one farmer, whereas the meadows of most of the farmers surveyed were composed only of "grass".

\subsubsection{Group 4: Natural environment integrated, management of semi-natural features improved}

The last group of farmers ( 3 farmers) integrated the natural environment most fully into the running of their farm. They had good knowledge of wild and domestic fauna and flora and appreciated the natural environment, even wild boar: "Once I saw a herd of boar (...) there were thirty or forty, lovely sight (...) I didn't have a camera, but I enjoyed seeing them!" They accepted crop damage by animals and tried to limit it, while at the same time showing respect for wildlife. These farmers considered that their farm formed an integral part of the natural ecosystem, which they felt it should disturb as little as possible. They asked themselves questions about the impact of their activity on the natural operation of the ecosystem or the lives of animals. They appreciated landscapes where human presence was discreet. Unlike in the other three groups, tidiness was not an objective. They felt that as farmers they were appreciated for their role in preserving land and landscape from urbanisation.

This representation of the natural environment was reflected in the farmers' practices: they conserved semi-natural features and sometimes planted new semi-natural features, especially tree-based. Upkeep of these features was not intensive but above all selective. Constraints were turned into advantages. The observation of semi-natural features and natural ecosystems was a source of inspiration for adapting agricultural practices. Concerning hedges, one fruit grower explained that "the point is to try and keep the species in place and not add any more, not to turn out beneficial organisms; why would I want to bring in a species that's not adapted here? (...) we're going to preserve what's here the best we can, we'll see over the years as we go along (...) we'll adapt." Permanent grasslands were managed with an eye on the quality of the forage produced for animal feed while attention was paid to mowing directions to prevent animals from being hurt: "when you mow meadows you see game; l'm careful (...) last year I was starting to mow this plot (...) I saw a lovely green lizard (...) I was careful, (...) I was pleased, he got away."

\section{Discussion and operational perspectives}

\subsection{Methodological considerations}

As seen above, in the interviews with the farmers, the issue of biodiversity and its links with farming practices was not directly addressed. Using aerial photography to show farmers their plots together with the semi-natural features on them proved to be a good technique for encouraging them to talk about their practices and perceptions with regard to these features. This method made it easier to address the subject of green belt measures through the materiality of 
ecological corridors, in particular semi-natural features. To a certain extent, it also made it possible to avoid farmers to focus on general comments about what 'others' think or do or declarations for or against environmental schemes or public environmental policy. That is why we introduced at the end of the interview the questions about their knowledge about green and blue belt provision and other environmental schemes.

According to the methodological framework adopted, the sample size was small and the interviews had no quantitative or representative value. This work could usefully be extended to other areas so that the results can be compared and consolidated. Nevertheless this methodology made it possible to better understand the farmers' frame of reference when they make a decision regarding semi-natural features.

\subsection{Advancement and discussion of results}

\subsubsection{Farmers' reasoning is not only linked to economic criteria: the advantage of a socio- agronomic approach}

Our study provides a deeper analysis of farmers' rationales about their practices regarding seminatural features and the way they represent semi-natural features and perceive 'nature'. The results of our survey confirm that the justifications underpinning farmers' practices and representations with respect to semi-natural features do not reflect technical and economic criteria alone, but also draw on more personal reasons connected to the notion of heritage, aesthetic concerns or family use (Thevenet et al., 2006; Larrère et al., 2007; Baudry et al., 2000).

On the one hand, the farm landscape is often described with reference to agricultural production activity, as noted by Petit (2012): for example, an overdeveloped hedge hinders the movement of farm machinery, the quality of grassland is evaluated by the appetence livestock have for grass or by the quality of the hay that can be harvested, and isolated trees are accepted, or even desired, to give shade to animals or to let them rub themselves against the trunks. On the other hand, many other reasons are given to justify farmers' practices and representations with respect to semi-natural features, reflecting more generally what they think of 'nature', with its composition of plant features, landscape and wild animals.

\subsubsection{The benefit of considering a range of semi-natural features}

One of the aims of our work was to consider not a single category of features but the main seminatural features able to form a biologic corridor. This is consistent with the idea that, for ecological reasons, and in particular as part of the effort to rebuild green corridors, the management of seminatural features must be seen at a global scale. In our sample, each farmer is generally concerned by several types of semi-natural features: woods and hedgerows are the most frequently encountered, being present on about $90 \%$ of the farms. Furthermore, when farmers make a decision regarding management and upkeep of semi-natural features, they have to take into account the overall running of their farm and the spatial pattern of the whole farmland. Such considerations can dictate the farmers' choices, for example when they do not have enough time to upkeep all the features on their farmland. As seen from the farmers' interviews, priority is sometimes given to those features that are relatively close to the farm or whose location may impede the passage of tractors.

\subsubsection{The influence of the local context}


Farmers' practices and representations appear to be strongly influenced by the local context because farmers felt themselves as integral parts of this local context. Even if these issues were not at the heart of the interviews, some farmers expressed their opinion about local agricultural land use policies, previous local environmental schemes, or key local issues regarding agriculture such as agricultural land abandonment and the ties between agriculture and urban concerns. These findings are consistent with those of Kristensen et al. (2001), who show that farmers' involvement in landscape activities (like hedgerow planting or removal, pond activities, cultivation of permanent grassland, etc.) does not only depend on the natural features of their farms or specific characteristics of the farms but also on a number of local factors.

Farmers live, work and make decisions in the context of an area designed and managed by and with other stakeholders, in particular land owners and local municipalities. Hence, the periurban area in which the farms surveyed here are located seems to affect farmers' practices and reasoning. Urban sprawl is taking up an increasing amount of agricultural land, generating an uncertain future for farmers and possibly preventing them from adopting a real development strategy. Some claim that they do not want to make any investments or spare time to upkeep hedgerows, woods or trees given the uncertainty surrounding the existence of their plots in the coming months or years. Other farmers feel that local policy makers do not recognise the importance of agricultural activities. This prevents them from engaging in environmental policies. After all, their major concern is the very existence of their farm in the future. On the other hand, some farmers feel particularly concerned by agricultural land abandonment and are aware of the role they can play managing nature.

\subsubsection{The land use issue}

The analysis of the farmers' statements reveals that land use issue can be a key driver of farmers' practices concerning management and upkeep of semi-natural features. Some farmers are tenants on part or all of their farmland and say that their landowners are generally in favour of keeping hedgerows when they would in fact prefer to remove them or trim them more severely. Most say that they have to comply with their landowners' preferences. However, many farmers consider that the way they upkeep landscape features demonstrates the 'quality' of their work. These farmers often use terms like 'tidiness' to describe their practices: This preoccupation with the 'tidiness' of the farmland can be linked to the context of strong competition for land in periurban areas (Alavoine-Mornas et al., 2014). Some farmers feel that if they present a good image of the way they work this will help them to rent new plots from landowners.

In the farmer profiles, we found different proportions of rented farming areas. In the groups of farmers who have low tolerance with regard with nature and no or little integration of semi-natural feature into the farm functioning, in average $70 \%$ of the utilised agricultural area per farm was rented, while this proportion was $47 \%$ for the groups of farmers who integrate nature and seminatural feature into their farming system and express a better opinion about biodiversity. These results suggest that a high proportion of rented farmland could have a negative influence on the farmers' perception of semi-natural features and on their willingness and commitment into schemes aimed at biodiversity preservation. These farmers might feel in a negative way the obligation to respect landowners' requirements. More generally they also might be reluctant to engage into environmental schemes on agricultural parcels which could not be part of their farmland in a few years. These observations should of course be tested in other farms in order to validate the relative importance of land use issue on farmers' practices and perceptions regarding semi-natural features compared with other factors. 
Anyway the land use issue is of crucial importance given that in France an increasing amount of agricultural land is rented land and that many landowners are former retired farmers or people who live locally. In our sample of 20 farms, in average $58 \%$ of utilised agricultural area is rented. Thirteen out of the twenty farms rent over $50 \%$ of the surface used while two farmers work on entirely rented land.

These findings also suggest that landowners' opinions and knowledge of semi-natural features are as important as farmers' and should be taken into account when policy makers intend to implement a biodiversity protection policy such as the green belt policy.

\subsection{Operational perspectives}

The work performed here highlights the diversity of farmers' attitudes and practices, diversity according to the semi-natural feature considered, diversity in space and time, and diversity according to the farmer. Thus, depending on its location, a semi-natural feature (in particular a hedgerow) does not have the same status, the same role or the same representation for a farmer. Farmers' practices and representations can also evolve according to experience gained, changes to workforce organisation, changes in context, and meetings - and sometimes conflicts - with other stakeholders, etc.

The evidence for different farmer profiles based on the degree to which the natural environment is integrated on their farms suggests that public authorities should adopt different approaches for the implementation of green belt provisions. The typology established may provide useful insights in this respect.

Type 1 farmers aim to control semi-natural features and more generally what they consider as 'nature'. Their priority is agricultural production and they are concerned about the image they portray to other local stakeholders. They do not seem to be very receptive towards the preservation of biodiversity suggesting that getting them to participate in training sessions on this subject may prove to be a challenge. However, this group of farmers may be interested in the results obtained by their neighbours and be open to the idea that biodiversity preservation and green belts provide useful services to agricultural production (beneficial species, shelterbelt, animal welfare, etc.).

The farmers in group 2 tolerate nature on their farm and generally tend to maintain semi-natural features. This suggests that it would not take much to encourage them to take environmental considerations into account in their practices, on the condition that these are not counter to their production objectives. The challenges they face should also be taken into account, in particular with respect to workload and labour organisation.

Types 3 and 4 are the most receptive to biodiversity preservation and green belt creation or maintenance. Type 4 farmers in particular have integrated the natural environment into the running of their farms and consider nature as a source of inspiration for improving agricultural practices. This group may well set an example for other farmers, on condition that they are not limited to the role of environmental service suppliers disconnected from production objectives.

Generally speaking, in order to implement the green belt provision at farm level, public authorities should take into account farmers' knowledge of biodiversity and 'nature', such as it is derived 
from their practice and observation of the functioning of ecosystems, as noted by Doré et al. (2011). All four types of farmers demonstrate some form of 'nature'-related knowledge. Although some farmers criticise environmental schemes, they also express an attachment to certain types of animal that they see in their everyday work (deer, fawns, etc.), while this attachment has nothing to do with their agricultural production.

It would be worth taking into account farmers' challenges and the specific characteristics of their farming systems. For example, the disadvantages of certain species for agricultural production must be considered. The emblematic case is the wild boar, which often causes damage to cultivated areas and grasslands. It is also necessary to keep in mind the workload required by the upkeep of semi-natural features and how such work can be integrated into the farming workforce organisation and annual work planning (Camacho et al., 2008).

Finally, the study also highlights the effect of local contexts and other local stakeholders on farmers' practices and their perceptions of semi-natural features and of public policies in favour of biodiversity and environmental preservation. In particular, the study shows how landowners encourage or oblige farmers to maintain hedgerows as part of an area's natural heritage. It demonstrates how farmers themselves maintain semi-natural features in an effort to keep the farmland 'tidy' and showcase their skills. This suggests that information about practices favourable to biological corridors and biodiversity preservation should be shared not only with farmers (who are often tenants of the land) but also with their landowners willing to participate in biodiversity protection (Moon et al., 2012). Furthermore, farmers' participation in environmental measures may be affected by the relations they have with local institutions (Taylor and Van Grieken, 2013) and how they perceive the place and role of agriculture in the local area, in particular in a periurban context where there are often conflicts between agriculture and other land uses.

\section{Conclusion}

This research confirms that implementing the green belt policy at farm level should be done in cooperation with the farmers concerned. As noted by Siebert et al. (2006), financial compensation and incentives are a necessary but insufficient condition to influence farmers' willingness and ability to co-operate with biodiversity policies. Many farmers would like their work to be recognised by society and public authorities (Fleury et al., 2015). They would like the specific characteristics and challenges of their farms, the context of their lives and work, and their knowledge to be taken into account. Most do not wish to be considered as enemies of biodiversity, believing instead that the very existence of their farms guarantees a certain biological and landscape diversity to which they contribute through their farming activity.

The knowledge garnered through this study relating to farmers' practices and representations regarding semi-natural features, their perception of the natural environment, and their justifications of the practices they adopt, should help public authorities to ease conflicts and find compromise solutions that combine environmental objectives with farmers' practices and perceptions, as championed by Henle et al. (2008).

Recommendations and communication relating to the implementation of the green belt policy should take into account the farmer profiles evidenced, as well as the different practices and representations with respect to semi-natural features on the same farm. By suitably adapting the 
messages delivered, and taking into account the farmer's frame of reference, it should be possible to foster a true integration of practices that favour the preservation or reconstitution of green belts.

\section{References}

Alavoine-Mornas F., Léger-Bosch C., Lanquetin J., 2014. Les agriculteurs périurbains : une place à trouver dans la gouvernance foncière territoriale. Canadian Journal of regional science / Revue canadienne des sciences régionales, 37(1/3), 47-57 (accepté le 11 décembre 2014)

Barbier J.M., Goulet F., 2012. Moins de technique, plus de nature : pour une heuristique des pratiques d'écologisation de l'agriculture. Nature, Sciences et Société, 2013/2 - Vol. 21, pages 200 à 210

Baudry J., Bunce R.G.H., Burel F., 2000. Hedgerows: an international perspective on their origin, function and management. Journal of environmental management, (2000) 60, p. 7-22.

Burel, F. et J. Baudry, 1999, Ecologie du paysage. Concepts, méthodes et applications, Editions Tec \& Doc, Paris, $359 \mathrm{p}$.

Busck A., 2002. Farmers' landscape decisions: relationships between farmers' values and landscape practices. Sociologia Ruralis, vol. 42, number 3, july 2002, p. 233-249

Camacho O., Dobremez L., Capillon A., 2008. Des broussailles dans les prairies alpines: organisation spatiale de l'activité et pratiques des éleveurs en vallée d'Abondance. Revue de Géographie Alpine, 96(3), 77-100.

Darré J.P., Mathieu A., Lasseur J. (coord.), 2004. Le sens des pratiques. Conceptions d'agriculteurs et modèles d'agronomes. INRA éditions, 2004, 320 p.

Deffontaine J.P., 2004. L'objet dans l'espace agricole. Le regard d'un géoagronome. Natures Sciences Sociétés 12, 299-304 (2004)

Doré T., Makowski D. Malézieux E., Munier-Jolain N., Tchamitchian M., Tittonell P., 2011. Facing up to the paradigm of ecological intensification in agronomy: revisiting methods, concepts and knowledge. European Journal of Agronomy, 34 (2011), p. 197-210

Dupraz C, Liagre F, 2011. Agroforesterie: des arbres et des cultures, ed. France Agricole.

Fleury P., Seres C., Dobremez L., Nettier B., Pauthenet Y, 2015. "Flowering Meadows", a resultoriented agri-environmental measure: Technical and value changes in favour of biodiversity. Land Use Policy, volume 46, July 2015, Pages 103-114.

Gilbert-Norton L. et al., 2010. A meta-analytic review of corridor effectiveness. Conservation Biology, volume 15, $n^{\circ 3}, 660-668$

Girard N., 2006. Catégoriser les pratiques d'agriculteurs pour reformuler un problème en partenariat. Une proposition méthodologique. Cahiers Agricultures vol. 15, n³, mai-juin 2006, p. 261-272 
Grashof-Bokdam C, Van Langevelde F., 2004. Green veining: landscape determinants of biodiversity in European agricultural landscapes. Landscape Ecology (2004), 20, p.417-439

Harvey, C.A., N.I.J. Tucker, and A. Estrada. 2004. Live Fences, Isolated Trees, and Windbreaks: Tools for Conserving Biodiversity. In: G. Schroth, G.A.B. da Fonseca, C.A. Harvey, C. Gascon, H.L. Vasconcelos, and A-M.N. Izac. Agroforestry and Biodiversity Conservation in Tropical Landscapes. Island Press, Washington, DC.

Henle K., Alard D., Clitherow J., Cobb P., Firbank L., Kull T., Mac Cracken D., Moritz R.F.A., Niemela J., Rebane M., Wascher D., Watt D., Young J., 2008. Identifying and managing the conflicts between agriculture and biodiversity conservation in Europe - A review. Agriculture, Ecosystems and Environment, 124 (2008), p.60-71

Jongman R.H.G., 1995. Nature conservation planning in Europe: developing ecological networks. Landscape and Urban Planning 32 (1995) 169-183

Jongman R.H.G, 2002. Homogenisation and fragmentation of the European landscapes: ecological consequences and solutions. Landscape and Urban Planning 58 (2002), 211-221.

Kelemen E., Nguyen G., Gomieroc T., Kovács E., Choisis J.P., Choisis N., Paoletti M. G., Podmaniczky L., Ryschawy J., Sarthou J.P., Herzog F., Dennis P., Balázs K., 2013. Farmers' perceptions of biodiversity: Lessons from a discourse-based deliberative valuation study. Land Use Policy, 35 (2013), p. 318-328

Kristensen et al., 2001. Farmers' involvement in landscape activities: An analysis of the relationship between farm location, farm characteristics and landscape changes in two study areas in Jutland, Denmark. Journal of Environmental Management (2001) 61, 301-318.

Larrère R., Fleury P., Payant L., 2007. La "nature" des éleveurs : sur les représentations de la biodiversité dans les Alpes du Nord. Ruralia 21 (2007), 14 p.

Le Roux X, Barbault R., Baudry J., Burel F., Doussan I., Garnier E., Herzog F., Lavorel S., Lifran R., Roger-Estrade J., Sarthoun J.P., Trommetter M. (éditeurs), 2008. Agriculture et biodiversité. Valoriser les synergies. Expertise scientifique collective, synthèse du rapport, INRA (France), $116 \mathrm{p}$.

Magda, D., de Sainte Marie, C., Plantureux, S. et al., 2015. Environmental Management (2015) 56: 1053. doi:10.1007/s00267-015-0553-6

Michel-Guillou E., 2006. Représentations sociales et pratiques sociales: l'exemple de l'engagement pro-environnemental en agriculture /Social representations and social practices: the example of the pro-environmental commitment in agriculture. Revue européenne de psychologie appliquée 56 (2006), p. 157-165

Moon K., Marshall N., Cocklin C., 2012. Personal circumstances and social characteristics as determinants of landholder participation in biodiversity conservation programs. Journal of Environmental Management, 113 (2012), 292-300.

Petit S., 2012. Savoirs de la pratique et savoirs scientifiques : rencontre dans les prairies du Haut-Jura. Agronomie, Environnement et Sociétés, volume 2, numéro 1, juin 2012, p.75-77 
Plantureux, S., Pottier, E., Carrère P., 2012. La prairie permanente : nouveaux enjeux, nouvelles définitions ? Fourrages, 211, 181-193.

Riley M., 2006. Reconsidering conceptualisations of farm conservation activity: The case of conserving hay meadows. Journal of Rural Studies 22 (2006) 337-353

Schmitzberger I. et al., 2005. How farming styles influence biodiversity maintenance in Austrian agricultural landscapes. Agriculture, Ecosystems and Environment 108 (2005) 274-290

Siebert R., Toogood M., Knierim A., 2006. Factors affecting European farmers participation un biodiversity policies. Sociologia Ruralis, vol. 46, number 4, October 2006, p. 318-340

Taylor B.M., Van Grieken M., 2015. Local institutions and farmer participation in agrienvironmental schemes. Journal of Rural Studies, 37 (2015), 10-19

Thévenet C., Dobremez L., Fleury P., Larrère R., 2006. Insertion de contrats de préservation de la biodiversité dans les exploitations agricoles des alpes du Nord. Fourrages (2006) 188, 495-510

Van Dam D., Nizet J., Streith M., 2012.Les émotions comme lien entre l'action collective et l'activité professionnelle : le cas de l'agriculture biologique. Nature, Sciences, Sociétés 20, 318329 (2012) 